\title{
Learning Malay Cultures and Cosmology Online Using Kabukos: What do the Learners Need?
}

Norhazlina Husin, Saliza Ismail, Midiyana Mohamad, Nor Azita Che Din, Sri Qamariah Mohd Samsir, Noor Hanim Rahmat

To Link this Article: http://dx.doi.org/10.6007/IJARBSS/v11-i11/11325 DOI:10.6007/IJARBSS/v11-i11/11325

Received: 09 September 2021, Revised: 14 October 2021, Accepted: 30 October 2021

Published Online: 15 November 2021

In-Text Citation: (Husin et al., 2021)

To Cite this Article: Husin, N., Ismail, S., Mohamad, M., Din, N. A. C., Samsir, S. Q. M., \& Rahmat, N. H. (2021). Learning Malay Cultures and Cosmology Online Using Kabukos: What do the Learners Need? International Journal of Academic Research in Business and Social Sciences, 11(11), 1133 - 1153.

Copyright: (C) 2021 The Author(s)

Published by Human Resource Management Academic Research Society (www.hrmars.com)

This article is published under the Creative Commons Attribution (CC BY 4.0) license. Anyone may reproduce, distribute, translate and create derivative works of this article (for both commercial and non-commercial purposes), subject to full attribution to the original publication and authors. The full terms of this license may be seen

at: http://creativecommons.org/licences/by/4.0/legalcode

Vol. 11, No. 11, 2021, Pg. 1133 - 1153

Full Terms \& Conditions of access and use can be found at http://hrmars.com/index.php/pages/detail/publication-ethics 


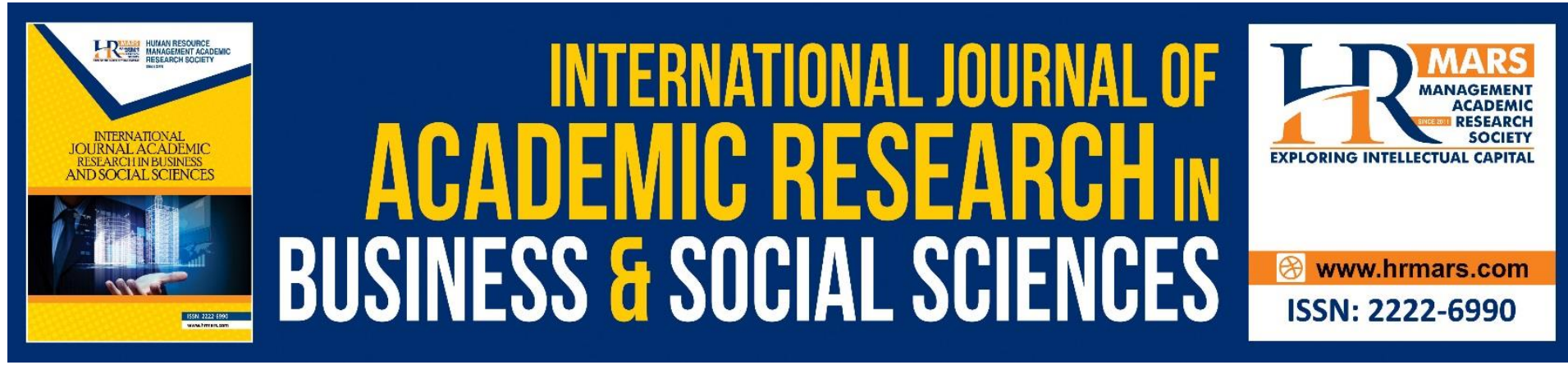

\title{
Learning Malay Cultures and Cosmology Online Using Kabukos: What do the Learners Need?
}

\author{
Norhazlina Husin, Saliza Ismail, Midiyana Mohamad, Nor Azita \\ Che Din \\ Universiti Teknologi MARA, Shah Alam \\ Email:norha462@uitm.edu.my, salizai@uitm.edu.my,midiy165@uitm.edu.my, \\ norazita@uitm.edu.my
}

Sri Qamariah Mohd Samsir

Universiti Teknologi MARA, Shah Alam

Email: sriqamariah@uitm.edu.my

\author{
Noor Hanim Rahmat \\ Akademi Pengajian Bahasa, Universiti Teknologi MARA Cawangan Johor, Campus Pasir \\ Gudang \\ Email: noorha763@uitm.edu,my
}

\begin{abstract}
Cultures and cosmology are intangible elements that need to be understood well. By adapting Connectivism Theory by Siemens (2004), a survey has been conducted to investigate students' perceptions of the needs and readiness of the use of KaBuKos. KaBuKos is an online mini dictionary of Malay Culture and Cosmology concepts using QR codeas online learning material. A questionnaire consisting of three sections was designed and distributed to 169 students who had taken the BMP447: Malay Culture and Cosmology course. Findings show that internet access can help respondents search for the required information on Malay Cultures and Cosmology concepts. Finding also shows respondents are willing to communicate online with their friends and lecturers if they do not understand the concepts. Findings also show that the respondents need online learning material that can be accessed any time and anywhere. They can use it for their preparation before class. It is believed that KaBuKos will empower lecturers and students in the online teaching and learning of Malay Culture and Cosmology concepts.
\end{abstract}

Keywords: KaBuKos, QR Code, Culture and Cosmology, Online Learning Materials

Introduction

Background of Study

Culture and cosmology are two intangible concepts that are always regarded as unamenable to learn and understand. Most of the concepts are abstracts and cannot be pictured 
physically. Therefore, students need to understand the concepts so that they can grasp the subject very well.

The learning of Malay Culture and Cosmology concepts can take place in so many ways. One of them is through extra learning material developed by the educators. In reference to the current education scenario, it is evident that online learning materials are more preferred compared to the physical books. Online learning or open and distance learning is a new norm in current education. Nevertheless, educators have to consider the students' needs and readiness. No student should be left behind.

A survey involving 169 students of Bachelor of Applied Linguistics Studies (Hons) Malay Language for Professional Communication was conducted to investigate their perception of the needs of online Malay Culture and Cosmology concepts learning material. It is hoped that findings from this survey will help improvise and enhance the usage of KaBuKos, a minidictionary using QR Code as learning material to learn and understand the Malay Culture and Cosmology concepts.

Objective and research questions

There are three objectives to be achieved in this study are through three research questions and they are;

- In what ways do KABUKOS attend to an individual's needs?

- In what ways do KOBUKOS comply with the task needs of learners?

- In what ways do KOBUKOS comply with organizational needs?

\section{Significance of the Study}

Pandemic Covid-19 that hit the world has changed the scenario of everyday life. It includes the teaching and learning of the BMP447 course. Students are no longer allowed to go for field studies to collect data and learn on-site. They depend solely on the online class.

Teaching culture and cosmology terms online may postulate difficulties specifically to students and educators. The learning span of students that are different can sometimes give difficulties to the educators.

Nowadays, learning a term in class without understanding it is seen as barely helpful for students. They need time to understand the terms and concepts learned. Simultaneously, lecturers or educators need to be more creative and innovative to ensure that the students do not lose interest in lessons.

Therefore, it is a big help if lecturers or educators can assist the students to comprehend better. One apparent element that is important is the use of media and technology. It is becoming more significant in teaching and learning. It is undeniable the advancement of technology has played a fantastic role in helping students learn.

KaBuKos is a mini dictionary innovated using QR codes. It assists the teaching and learning of Malay cultures and cosmology terms and concepts. It is the first of its kind in the teaching and learning of Malay culture and cosmology. It is easily accessible at any time and anywhere. One only needs to have a device with internet access. 


\section{Literature Review}

How are Malay Culture and Cosmology learned?

Culture is a manifestation and shared patterns of interaction and behaviours, cognitive constructs, and understanding. It is learned and embraced by socialization (Husin, 2016). It is an enigma that consists of concrete and abstract components (Ting-Toomey, 1999). It influences behaviour and direct socialization (Husin, 2016). Spencer-Oatey in GarcíaCarbonell \& Rising (2006) represents the different layers of depth, ranging from inner core assumptions and values, through outer core attitudes, beliefs, and social conventions, to surface-level behavioural manifestations.

Culture is not natural, inborn, and willess; it is a social product (Tengku Mahadi, \& Jafari, 2012). To understand our society's complex culture, we need to learn about it. But why do we need to learn culture? Besides influencing humans whether, through knowledge and belief, norms and values, or language and symbol (Scupin \& DeCorse, 2001; Thio, 2005), culture can also shape the behaviour of members of society. For instance, the system of a country administration is deemed as the 'power that be' that can determine the behaviour of a society (Husin, 2016).

Culture can be acquired in many ways. Whether it is taught and learned in a formal or informal situation, the bottom line is that it can still be learned. In Malaysia, cultures are also taught in classes. Numerous universities in Malaysia offer cultural-based courses as elective or core courses. The teaching and learning methods are also varied. The assessment methods used to assess students' understanding and skills also vary, depending on the learning outcomes. If culture is taught as a course, it will encompass every aspect of life, be it tangible or intangible, material or non-material. The cultural aspects taught may become useful as they are incorporated into their daily lives. Establishing culture as a course offers opportunities for the students to learn and experience the norms, beliefs, customs, morale, and philosophy in life.

Culture is also widely used in language learning. Culture and language are closely interrelated. The nature of language itself reflects the culture of a society. Language is the extended presentation of culture. This statement is consistent with Stockwell (2018), who believes that language and culture are closely interconnected, and students cannot fully grasp a language without understanding its culture.

Culture taught in a language for foreign speakers classes create an enthralling language class. It also helps students explore the culture of the society and acquire the language and culture more directly. More information can be obtained if more cultural activities are organised during the learning process (Baharudin \& Ikhsan, 2016).

Local culture is significant in learning a language like Arabic because it plays a vital role in determining the accuracy of the meaning of utterances and language used. The choice of words and sentence patterns are limited and determined by the local culture (Abdul Rahman \& Jabar, 2019).

Learning culture for so long has been helped by the abundance of books published. Commonly, every society or country publishes books depicting their cultures. It is due to the role played by culture. It does not only teach people how to behave but also shapes and develops a nation. Students only need to make their choices and read up on them. Not only that, many blogs, websites, or even wikis share a lot of information on culture. Finding it tough to learn cultural terms and concepts should not be an excuse in any way. Everything is just at our fingertips. 
Today, learning culture has also undergone considerable changes. The public perception that seems to view learning culture as having its limitations should be refrained from. There are many platforms, tools, and mediums that can be utilised to learn the culture. The rapid growth of the digital era has changed the way of life in so many ways. Cultural aspects such as customs and worldview are no longer given due attention. Technology has been claimed to be utilised of the main factors that contribute to this.

It is undeniable that technology does help a lot in our daily lives. However, technology can also be utilised to teach and learn the culture. For example, Marbel Belajar Budaya Nusantara, an application developed to help Indonesian kids learn about their culture. This application allows the learners to learn as they play. It introduces Nusantara cultures such as traditional costumes, traditional houses, musical instruments, traditional dances, and traditional foods. The developer hopes that this application will help introduce Nusantara culture to young kids in Indonesia to help them grow with proper morality ingrained.

KaBuKos is another example of learning material developed to help students to learn Malay culture and cosmology concepts. It helps to facilitate the students' online learning. This learning material is a shred of evidence that culture can also be instilled through the utilisation of technology.

\section{Online Learning}

Online or electronic learning is defined as learning that is enabled electronically. It enables the acquisition of knowledge through electronic technologies and media. Technically, online learning, also known as e-learning, is conducted on the Internet, where students can access their learning materials online at any place and time. Online learning is also referred to as web-based training, distributed learning, Internet-based learning, web-based instruction, cyberlearning, virtual learning, or net-based learning (Urdan \& Weggen, 2000). Online learning has been practised for so many years. Today, online learning is no more an alien to the world. It has been practised worldwide without any boundaries.

Online learning through networked computers has been available since the early 1990s, coinciding with the increased access to hardware and the internet. Early opportunities for online learning tended to be at the tertiary level. However, as computer hardware and software have evolved and become more widespread over the past several years, the opportunity to learn online is increasingly open (Hockly, 2015), especially in these two recent years. The Covid-19 pandemic that hit the world forbids face-to-face teaching and learning in some countries. This is the best time to practice and experience online learning.

The traditional form of teaching and learning gives more space to the teacher or educator's role. It is the active part of a class and students have a passive role. On aggregate, traditional teaching highlights competition, standard instruction for all, allocated specific time and location for instruction. It impliesa one-way instruction, that is, from teacher to student. However, online learning emphasises group cooperation, production, and application of knowledge and appropriate instruction. It is consistent with learner abilities. It also gives more opportunities to the students to learn according to time and place that suit their convenience. Online learning is not subjected to specific fields or subjects taught. Any subject, class, or course can be learned through online learning. This includes culture classes such as the BMP447 course. As with other courses taught, this course is also conducted online. It is hoped that at the end of the semester, students can translate their knowledge of Malay culture and cosmology into their daily lives as well as demonstrate their skills in practising the Malay culture and cosmology customs and philosophy in their daily lives. 
There are several online learning models introduced and practised. Online learning models describe where technology plays a specific role in supporting learning. These can be described as both at the pedagogical level and the level of detailed practise of those principles. Among them are models proposed by (Tsai, 2009; Salmon, 2013).

Model of Strategic e-Learning as proposed by Tsai (2009) explains student online learning from metacognitive perspectives. The model identifies four characteristics of online learning environments, namely: flexible time and space, indirect social interactions, abundant information resources, and dynamic learning interfaces. Figure 1 shows the models identified.

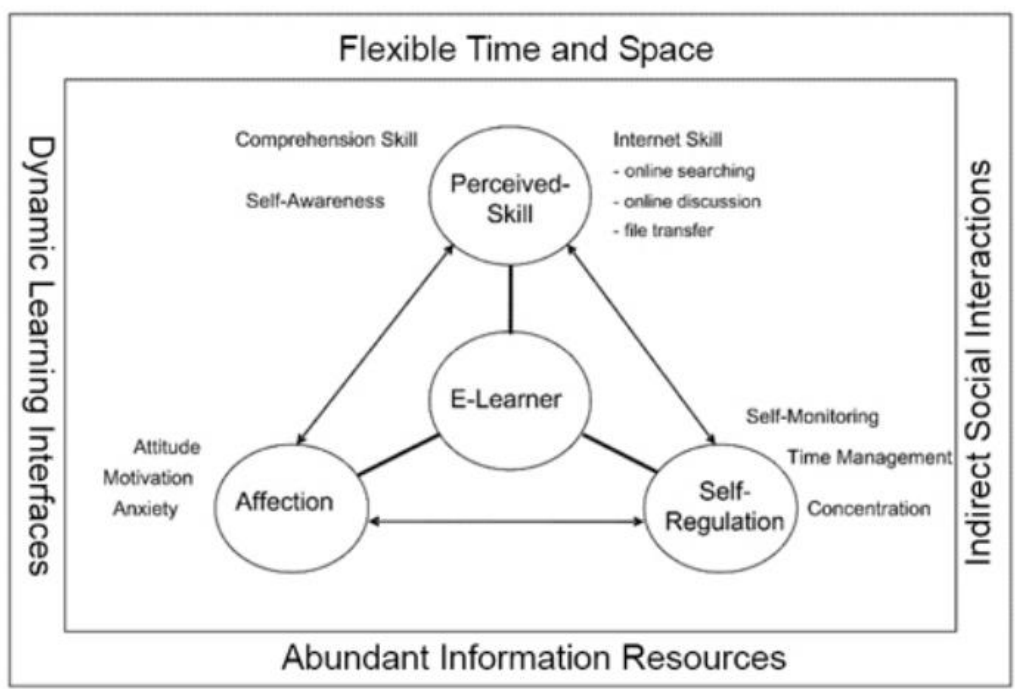

Figure 1: Model of Strategic e-Learning, (Source: Tsai, 2009)

According to Tsai (2009) in Figure 1, flexible time and space mean all online learning tasks can be performed at any time or place as long as they have Internet access. Online learning allows indirect social interaction between teachers and students. Students will have abundant information resources through online learning. The abundance and diversity of information resources are the greatest advantages of Internet-based learning. Students can immediately retrieve information around the world only if they link to the Internet. The Model of Strategic e-Learning also proves that online learning is a dynamic learning interface. Internet technology is used to create a learning platform for interactions among students and teachers. Due to the technology advancing rapidly, the interfaces changing with time dynamically is a specific feature of online learning systems.

Salmon (2013) in her book "E-tivities - the key to active online learning" states that the key to active and interactive online teaching and learning lies in bringing us greater interaction and group participation. She believes that from these small beginnings, a new body of practice will build up around e-tivities that will transfer to new technologies as they become available. She claims that the need for skilful e-moderations will not disappear, regardless of how sophisticated and fast-moving the technological environments become. E-moderators add real value to learning technologies by designing and running e-tivities. She proposes a model of online learning shown in Figure 2. 


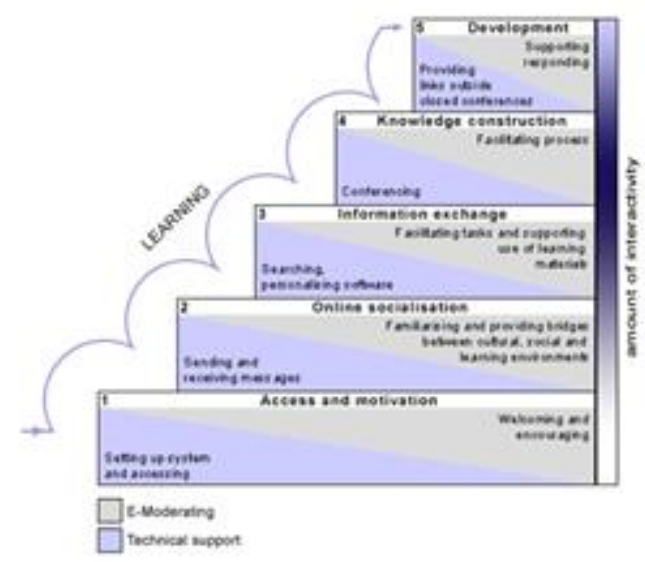

Figure 2: Model of "E-tivities - the key to active online-learning" (Source: Salmon, 2013)

Based on Figure 2: Salmon (2013) proposes five stages of E-tivities. Stage 1: involves individual access and the induction of participants into online learning. These are essential prerequisites for online conference participation. In Stage 2: individual participants establish their online identities and then find others to whom they interact. Participants will engage in a mutual exchange of information in Stage 3. Up to and including stage 3, a cast of cooperation occurs whereby each person supports the other participants' goals.

Course-related group discussions developed as well as the interaction became more collaborative in Stage 4. At this stage, collaboration requires an active sharing of information and intellectual resources amongst the participants. It enables them to work together in small groups toward a common goal. In Stage 5, participants look for more benefits from the system to help them achieve personal goals and reflect on the learning processes. Based on this model, the students are responsible for the learning of others as well as their own. Thus, the success of one student helps other students to be successful.

Learning environments, the processes, the networks, and the tools involved should be taken into account by the educators or lecturers. Students need a conducive environment to learn and need networks that can help them to collaborate and communicate. Whether it is asynchronous, synchronous, or hybrid online learning, communication and collaboration do not only occur among students but also with the lecturers. At the same time, lecturers have to ensure that appropriate tools or materials are utilised.

\section{Connectivism in Malay Culture and Cosmology Online Class}

Online learning connects people in the learning community. It also creates a conducive and convenient learning and communication environment for the students. It is consistent with what connectivism has introduced.

Connectivism is a learning theory that explains how Internet technologies have created new opportunities for society to learn and share information across the World Wide Web and among themselves. These technologies include Web browsers, email, wikis, online discussion forums, social networks, YouTube, and any other tool which enables the users to learn and share information with other people (Siemens, 2004).

The asynchronous nature of these interaction modes meant that the Internet is regarded as a support system to mediate community interaction and simulate learning (Shriram \& Warner, 2010). A key feature of connectivism is that much learning can happen across peer networks that take place online. A connected community around this shared information often results (Siemens, 2004). 
The learning process will still occur even though it is not face-to-face. There will be interactions between lecturers and students, students and students, students and the learning sources through an open and online environment that permits collaborative teaching and learning (Bahrum \& Samsudin, 2021).

Connectivism supports individual perspectives and the diversity of opinions. Theoretically, it provides for no hierarchy in the value of knowledge (Siemens, 2004). Therefore, it is applicable in online learning as implemented in the teaching of Malay cultures and cosmology. In this era of technology, students are more attracted to learning using technology. They can get information, instruction from the educators, or connected to their peers.

This study adopts four principles of the connectivism theory (Siemens, 2004), namely (i) autonomy, (ii) connectedness, (iii) diversity, and (iv) openness. In the context of the development and usage of the KaBuKos QR Code, lecturers have the autonomy to choose and decide which terms and concepts to be included in the mini-dictionary. The concepts are chosen based on the continuous use of the terms and concepts, not only during the class but also for their life-long learning management. It also explains the terms and concepts in very plain and simple language so that the students will easily understand them.

Connectivism shifts the learning responsibilities from the teacher to the student. It is up to the learner to create their own learning experience (Siemens, 2004). As for the students, they have the autonomy to choose, read and revise the Malay cultures and cosmology concepts and terms based on their needs be it for assignments, tests, discussions, or exams without any limitation to the time and space.

Technology has been the main actor in the era of information technology. The wide use of computers, computer tablets, and smartphones among the students helps in the learning process. Both the students and the educator can benefit from connectivism in the classroom. They can communicate, discuss and interact with more flexibility, better, faster, and effectively if compared to face-to-face learning. Therefore, by using KaBuKos in the QR code, students can access the dictionary anytime and anywhere.

The learning of Malay cultures and cosmology using the KaBuKos QR Code offers openness to the students or anyone using it. Users can access the code only by using a device with an internet connection. And this is not something new in today's life because a device with an internet connection is deemed as a necessity. This can act as a catalyst to more open and efficient learning of cultures.

\section{KaBuKos, a mini-dictionary using QR Code}

An online learning material has been developed to accommodate the teaching and learning of Malay culture and cosmology concepts. This online learning material, KaBuKos (Kamus Mini Konsep Budaya dan Kosmologi Melayu), is a mini-dictionary that comprises 50 terms taken from 10 topics taught in the Malay Culture and Cosmology (Budaya dan Kosmologi Melayu: BMP447) course. It was developed using QR Code (Quick Response) and shared with the students. QR codes facilitate students to access the lesson, information anywhere and anytime (Martin et. al., 2013).

M-learning using QR codes will be easier for the students. They do not have to carry heavier books. They only need to use devices to access the QR code (Hassan et. al., 2021). Nevertheless, the use of $Q R$ codes in education is still relatively new compared to its wide usage in logistics and technology (Baik, 2012).

The use of QR codes in education provides an opportunity to expand its use in teaching and learning in the new era of information technology. Furthermore, a pandemic that hit the 
world offers more opportunities to innovate in teaching and learning practices. Studies show that the use of QR codes in education has given many benefits, especially to the students. QR Code as an online learning material helps ease the learning process because it is an easily accessed, convenient, and comprehensible reference. Students will enjoy more flexible learning anywhere and anytime in a group or individually (Hassan et. al., 2021; Saleh et. al., 2018; Zaini et. al., 2016).

The application of the QR codes in education can enhance students' interest to read more (Hassan et. al., 2021) and help them to be more focused (Saleh et, al., 2018). It ensures that the students will get a quality education even though we are amid a pandemic. Therefore, the use of QR codes in education can generate positive vibes among the students (Kopf et. al., 2005) and it has been widely used in many sectors and fields such as library management, language learning, and health. Nevertheless, its use in the teaching and learning of Malay cultures is still lacking in studies. It is hoped that this study can serve as a platform for more studies on the online teaching and learning of Malay cultures and cosmology.

\section{Needs of Learners}

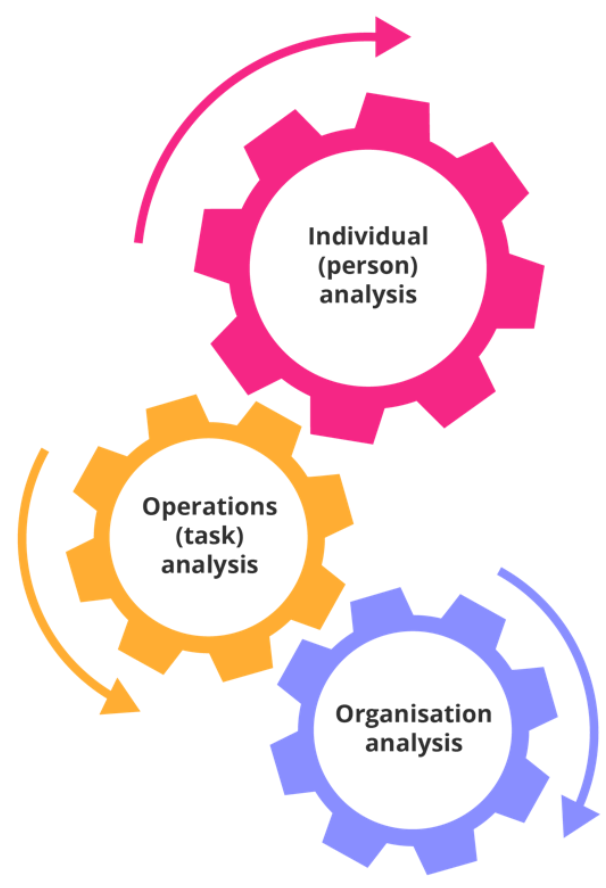

Figure 2: Three-Level Needs Analysis

(Source: McGhee and Thayer, 1961)

Figure 2 shows the three-level needs analysis by McGhee and Thayer (1961).

Needs analysis focuses on the requirements needed by learners to learn a course. The first level is the individual level. The needs analysis focuses on what the individual learner needs to make his/her learning effective. Next, the operations level is where the tasks in the course content are analysed to suit the needs of the learners. Finally, the organizational analysis is done to see what or how the organisation improves to make learning effective. 


\section{Past Studies}

Past studies on Learning Culture and Cosmology Concepts

Studies on the learning of culture and cosmology concepts are still relatively new. But there are studies on cosmology and culture carried out. One of them is a study by Shamsudin and Mat Akhir (2018) that aims to look at Comparative Analysis of Aspects of Creation of the Universe Based on al-Quran and al-Sunnah between the Malay Cosmology and Islamic Cosmology. This qualitative study aims to study the Malay and Islamic cosmologies by comparing the two in light of the aspect of natural creation. The comparison is supported by the evidence found in the al-Quran and al-Sunnah. Data were collected from the major works of tafsir and hadith through library research. The data collected were analysed based on inductive and deductive methods. Findings show that there are some elements of Malay cosmology that coincide with the teachings found in the al-Quran and hadith. However, there are some which contradict both sources one of which is the Nur Muhammad concept. The study also claims that the discussion on Malay cosmology is inseparable from the lives of the Malay community. It plays a role in the formation of the Malay civilisation. It is also found that their beliefs of nature are among the dimensions that shaped the Malay civilisation. These beliefs had a massive shift with regards to the creation of the universe. However, the traditional belief system originated from animism and Hindu-Buddhism are hard to recuperate from.

A study conducted by Yakin (2017) looks at the changes in customs and death rituals of the Bajau community due to the influence of the Islamic belief system and religion. This qualitative study uses an ethnographic approach to describe and interpret the semiotics in the customs and rituals of Bajau's death in Kota Belud. This study uses participatory observation and interview as its research methods. The results of the study show that the structure and symbols of death of the Bajau community in Kota Belud have the cosmological influence of Hinduism and Buddhism due to the animistic beliefs. However, the cultural practices of this community have also changed after they embrace Islam. These death customs and rituals indicate the existence of an adaptation and mixing of traditional and new beliefs. However, changes may take place more drastically in the future because the processes of Islamic purification are still ongoing.

These two studies prove that culture is also vital to be studied. Culture does not only teach people how to act, speak and think accordingly. It also gives opportunities to people to learn about themselves, their cultures and others'. These two studies also prove that culture can be learned (Husin, 2016; Mahadi \& Jafari, 2012). The study of Malay culture and cosmology is not new. The same goes for comparative studies on Malay culture and cosmology with other cultures. But a study on online Malay culture and cosmology concepts learning material is still not widely implemented. It is hoped that this study will initiate many more studies with similar aspirations.

Past Studies on Online Learning Material

Past studies show that online learning materials do help a lot in learning. In recent years, research works that aim to designate an online learning environment based upon learning styles have increased substantially. What more in this pandemic time. Today's online learning does not involve just the presentation and delivery of the materials but also involves access to the online learning material, interaction with lecturers, content, and other learners 
(Anderson \& Elloumi, 2004). Studies by Zamari et. al (2012); Erlina (2018) show that there is a need for online learning materials to facilitate the students' learning.

A study on Students' Perception of Using Online Language Learning Materials by Zamari et. al (2012) shows that online language learning has to consider learning materials because it can facilitate online learning. A questionnaire was designed and distributed to 100 UiTM firstsemester students to discover their perceptions and collective experiences upon completing online tasks given. They are required to take an active role in their own learning experiences through the use of online language learning materials to support their learning activities. Students were given a maximum of ten (10) marks for this assignment. Data obtained from 97 returned questionnaires shows that there are six main issues found; namely frequency of website visits, choice, recommendation, problems faced, students' opinion on the effectiveness of the task given, and students" initiative to access these websites. The study also suggests that lecturers must be more selective in recommending functional and beneficial web-based language learning materials to create more interest and encourage maximum participation. Most of the students have an internal motivation to use the Internet to facilitate their learning.

Another study by Erlina (2018) also shows that online learning materials can play a role in students' learning. She studied the students' perception towards the use of authentic online materials for speaking in English as a Foreign Language class. From her research, it is found that the students perceived that the use of authentic online learning materials is helpful and useful for them in improving their speaking skills. The study involves 17 students taking speaking classes at the English Education Study Program of Sriwijaya University. All students $(100 \%)$ agree that authentic online learning materials are good to be used in speaking classes. $T$ makes them more creative, has high imagination, and enjoy the lesson very much. In addition, the use of authentic online learning materials makes them involved in real-life activities, such as searching for information based on the topic of discussion, such as arranging a holiday trip.

It is found that there are still insufficient research conducted on the Malay Culture and Cosmology concepts learning materials. Most researches tend to focus on the cultural aspects being embedded in other classes than the culture class itself. Hence, there is a pressing need for research on online Malay Culture and Cosmology learning material. 


\section{Conceptual Framework of the Study}

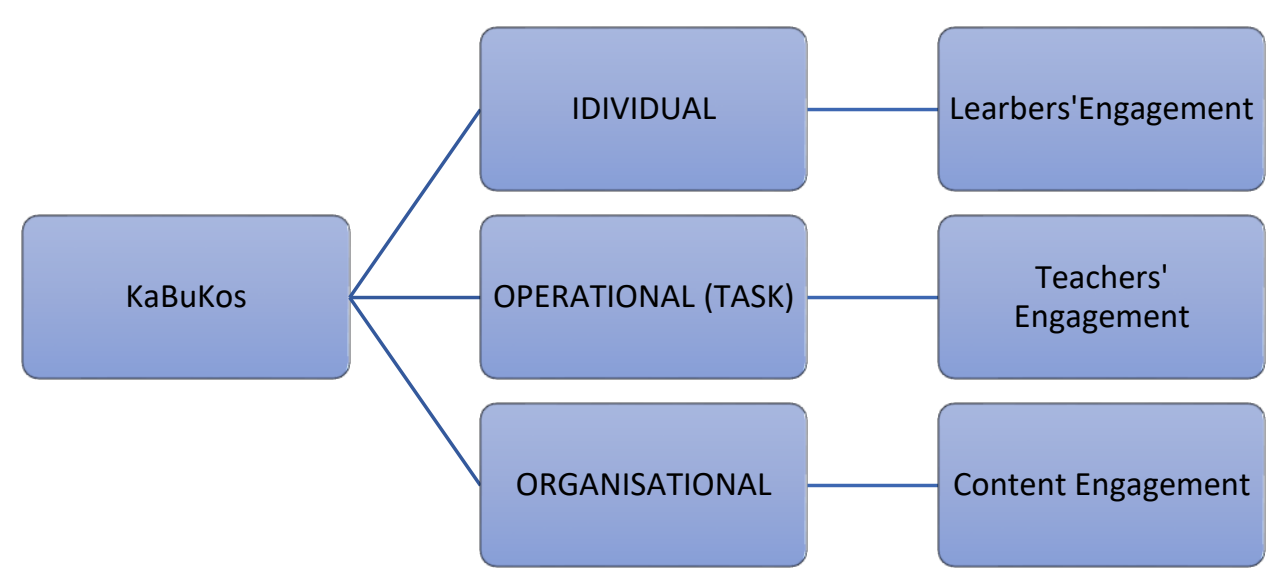

Figure 3-Conceptual Framework of the study

This study is rooted in the needs analysis factors by McGhee and Thayer (1961). The three factors are (a) individual needs, (b) operational (task) needs, and (c) organisational needs. The three need-factors are then scaffolded onto Martin \& Bollinger's (2018) three types of engagement in online learning to portray the use of KOBUKOS online. Individual needs are fulfilled through learners' engagement online. Operational (task)needs are fulfilled through teachers' engagement and organisational needs are fulfilled through content engagement.

\section{Methodology}

This quantitative study is done to explore the use of KOBUKOS in online classrooms 169 respondents participated in this study. The instrument used is a survey (table 1 ).

Table 1- Distribution of Instrument

\begin{tabular}{|l|l|l|l|}
\hline SECTION & NEEDS & $\begin{array}{l}\text { ONLINE } \\
\text { ENGAGEMENT }\end{array}$ & No of Items \\
\hline B & INDIVIDUAL & Learners with peers & 5 \\
\hline C & OPERATIONAL & $\begin{array}{l}\text { Teachers with } \\
\text { learners }\end{array}$ & 6 \\
\hline D & ORGANISATIONAL & Learners with content & 9 \\
\hline & TOTAL NO OF ITEMS & 20 \\
\hline
\end{tabular}

Table 2-Reliability Statistics

\section{Reliability Statistics}

\begin{tabular}{c|r}
$\begin{array}{c}\text { Cronbach's } \\
\text { Alpha }\end{array}$ & N of Items \\
\hline .914 & 20 \\
\hline
\end{tabular}


SPSS analysis (Table 2) shows a Cronbach alpha of .914; thus revealing high internal reliability for the instrument.

\section{Findings}

This section presents findings for the study. The first section presents findings from the demographic profile in percentages and the next sections present findings in terms of mean scores to answer the research questions.

Findings for Demographic Profile

Q1 Gender

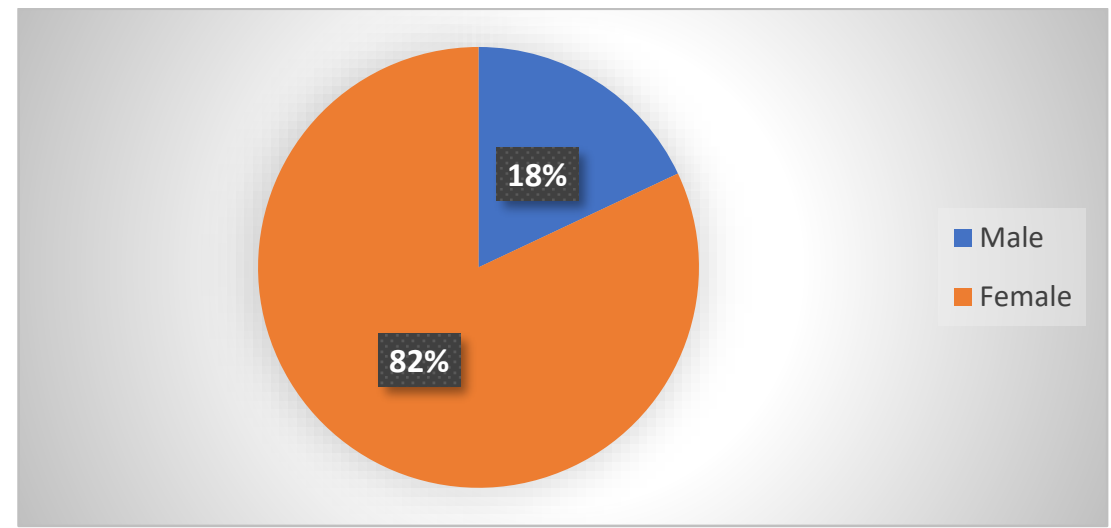

Figure 4- Percentage for Gender

Figure 4 indicates the gender distribution of the respondents. $82 \%$ of the respondents are female whereas $18 \%$ are male.

Q2 Semester

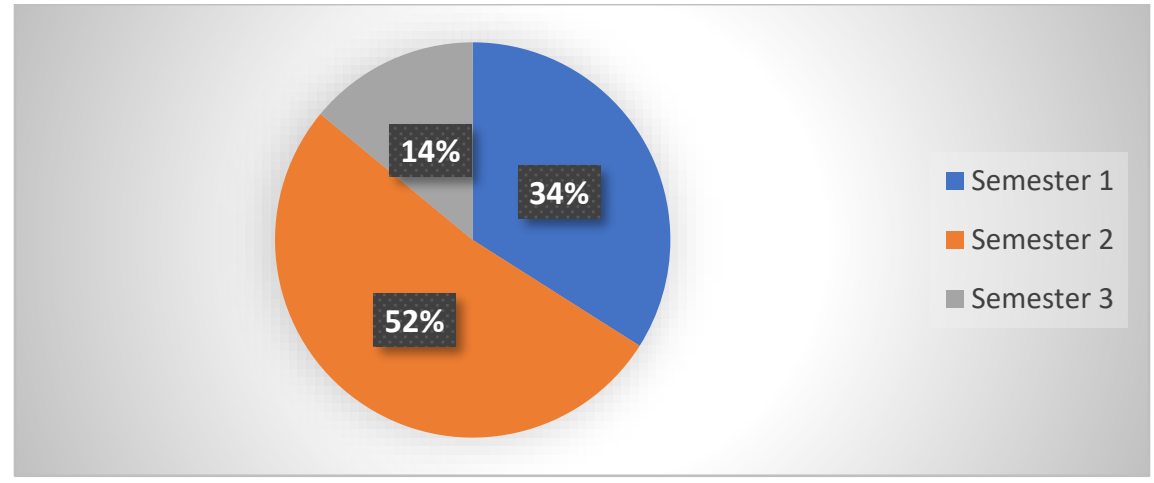

Figure 5- Percentage for Semester

The respondents were divided into three groups according to their semesters; Semester 1, Semester 2, and Semester 3 in Figure 5. Most of the respondents are from Semester 2 (52\%), $34 \%$ of respondents are in Semester 1, and only 14\% respondents from Semester 3. 


\section{Q3 Level of Education}

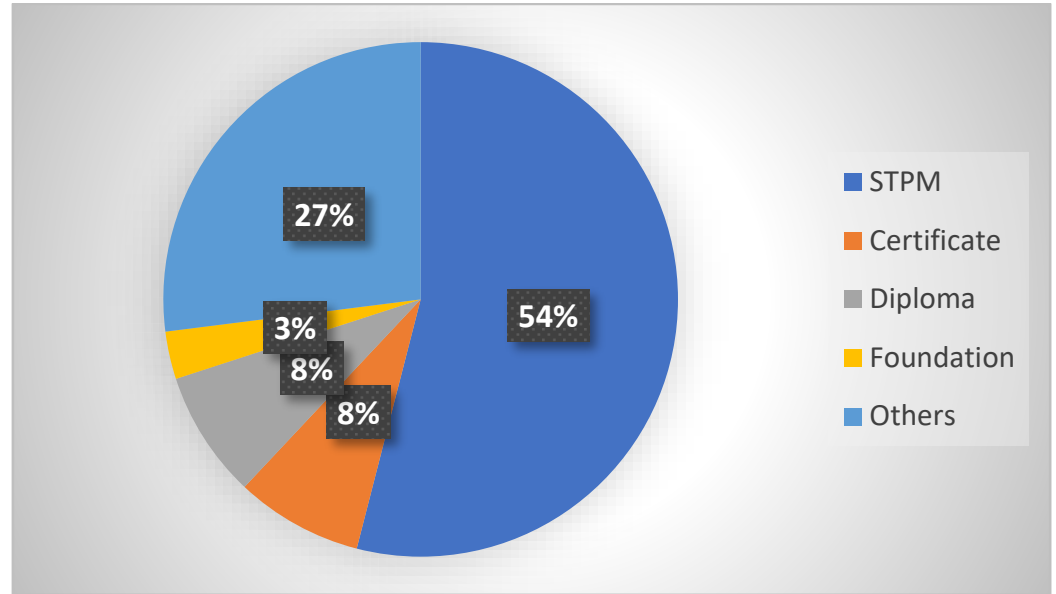

Figure 6- percentage for Level of Education

The level of education offers five options; STPM, certificate, diploma, foundation, and others. Figure 6 shows the level of education of the respondents. 54\% of the respondents had completed their STPM and $27 \%$ are others. A very small percentage of respondents had completed their certificate and diploma, equivalent to $8 \%$ and only $3 \%$ completed their foundation.

\section{Q4 Area of Residence}



Figure 7-Percentage for Area of Residence

The area of residence is divided into two groups which are urban area and rural area. Figure 7 shows that $52 \%$ of the respondents stay in the rural area and $48 \%$ stay in the urban area. 
Q5 I have taken Malay Culture and Cosmology course (BMP447)

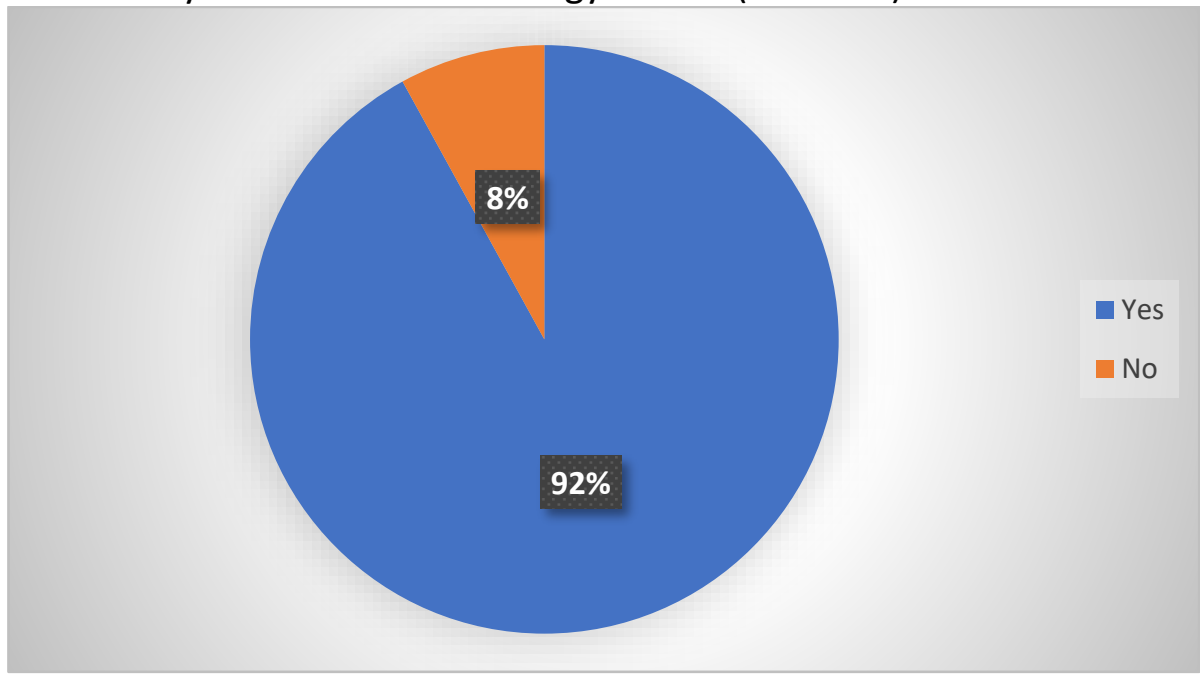

Figure 8- Percentage for Malay Culture and Cosmology

Concerning the Malay culture and cosmology course in Figure 8, 92\% of respondents answered they had taken the course. A small percentage of respondents answered they are yet to take the course (8\%).

\section{Findings for Individual Needs}

This section presents data to answer research question 1: In what ways do KaBuKos attend to INDIVIDUAL's needs?

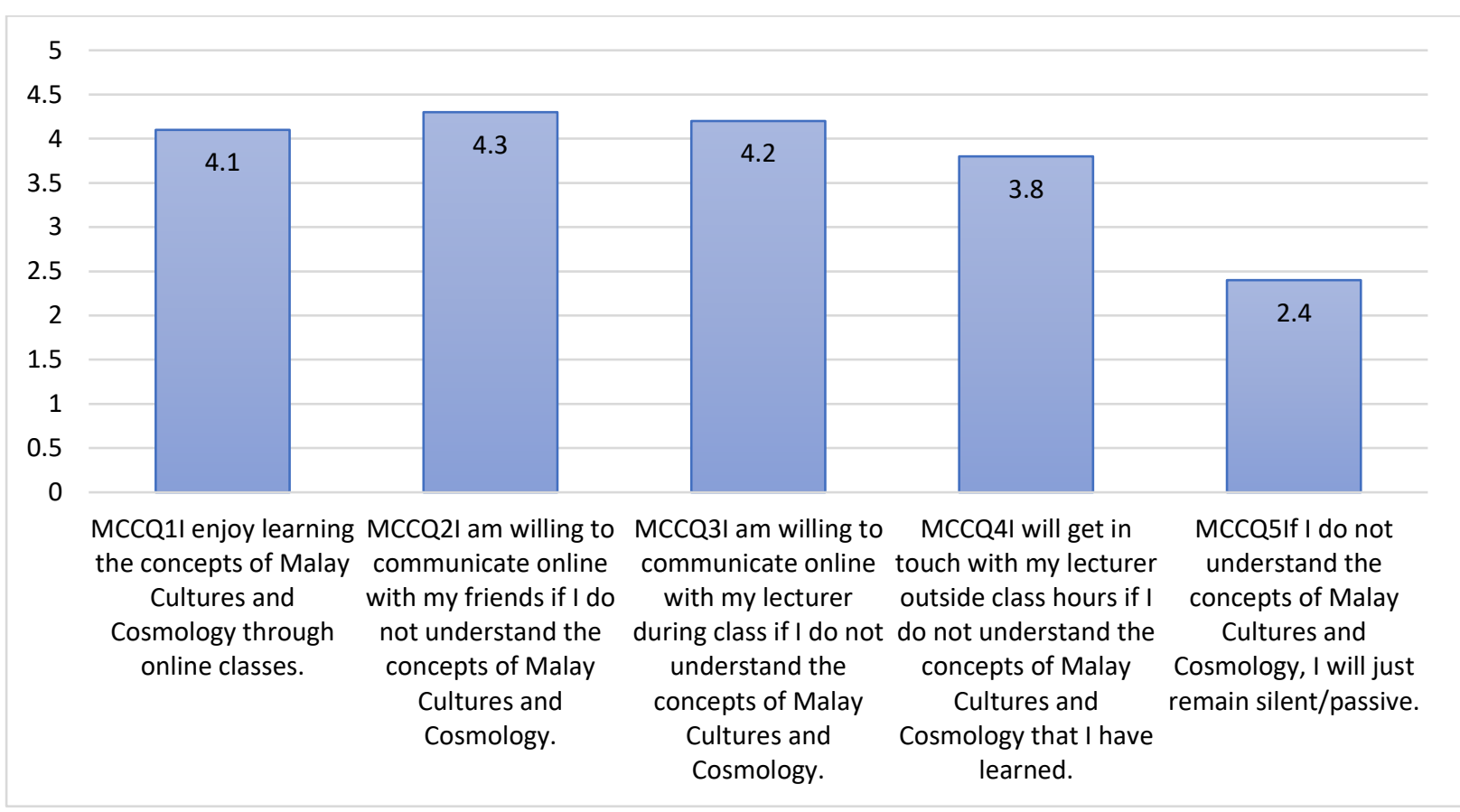

Figure 8-Mean for Individual needs

Figure 8 shows the perception of respondents' needs. Most of the respondents enjoy learning the Malay culture and cosmology concepts through online classes $(M=4.1)$. They are also willing to communicate online with their friends $(M=4.3)$ and their lecturers $(M=4.2)$ if they do not understand the concepts learned. They will get in touch with their lecturers outside 
class hours if they do not understand the Malay Cultures and Cosmology concepts that they have learned $(M=3.8)$. However, most of the respondents will not remain silent if they do not understand the Malay culture and cosmology concepts. They disagree with the statement given saying that if they do not understand the concepts of Malay Cultures and Cosmology, they will just remain silent/passive $(M=2.4)$.

\section{Findings for Task Needs}

This section presents data to answer research question 2: In what ways do KaBuKos comply with the task needs of learners?

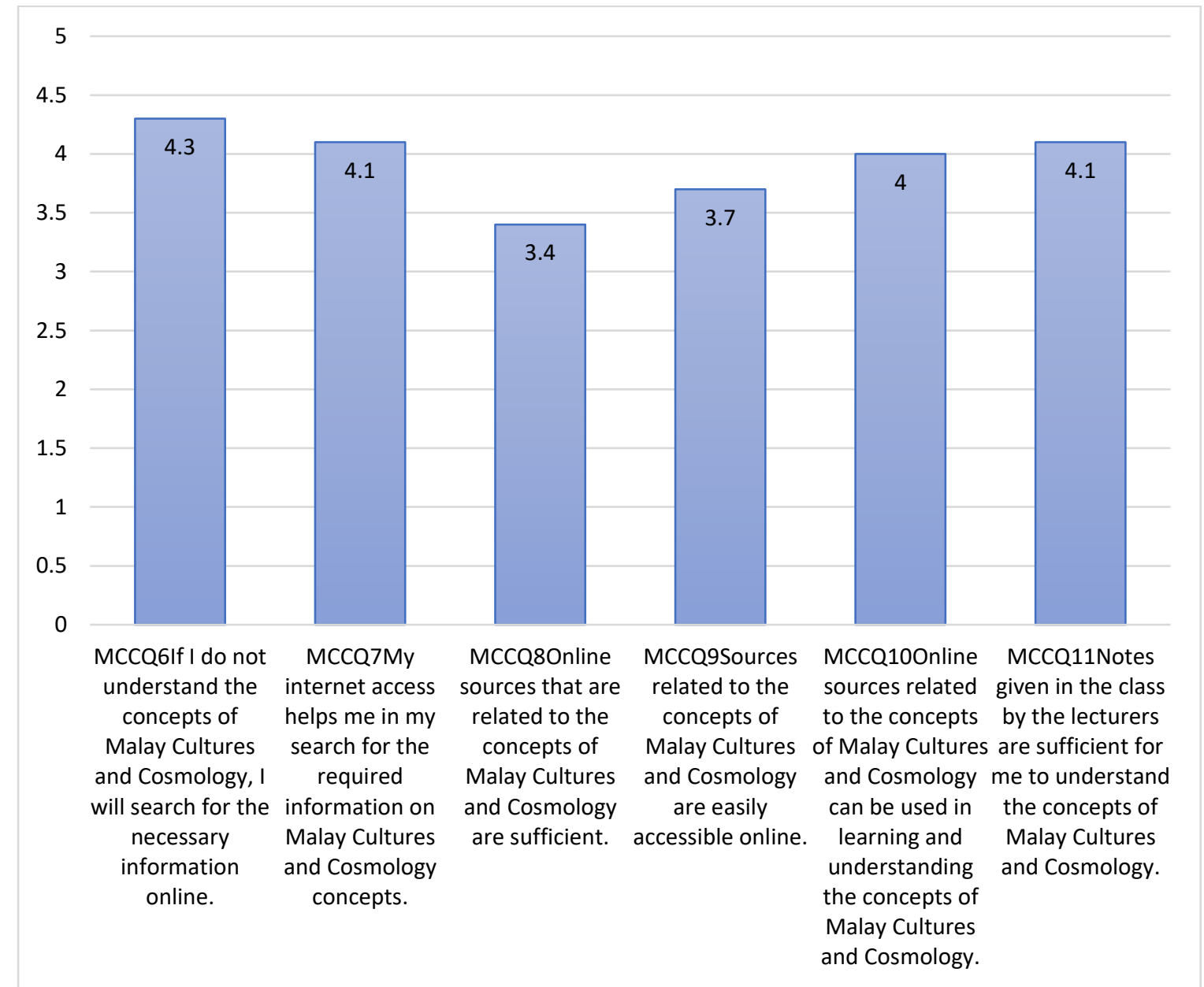

Figure 9-Mean for Task Needs

Figure 9 is the distribution of respondents' perception of course requirements. Most respondents agree that they will search for the necessary information online if they do not understand the Malay Cultures and Cosmology concepts $(M=4.3)$. They agree that online sources related to the Malay Cultures and Cosmology can be utlised in learning and understanding the Malay Cultures and Cosmology concepts $(M=4)$. However, most respondents agree that online sources related to the Malay Cultures and Cosmology concepts are insufficient $(M=3.4)$. Most respondents agree that sources related to the Malay Cultures and Cosmology concepts are easily accessed online $(M=3.7)$. Most respondents agree that online sources related to the Malay Cultures and Cosmology can be utilised in learning and understanding the Malay Cultures and Cosmology concepts $(M=4)$. Respondents also agree 
that notes given in the class by the lecturers are sufficient for them to understand the Malay Cultures and Cosmology concepts ( $M=4.1)$.

\section{Findings for Organizational Need}

This section presents data to answer research question 3: In what ways do KOBUKOS comply with organisational needs?

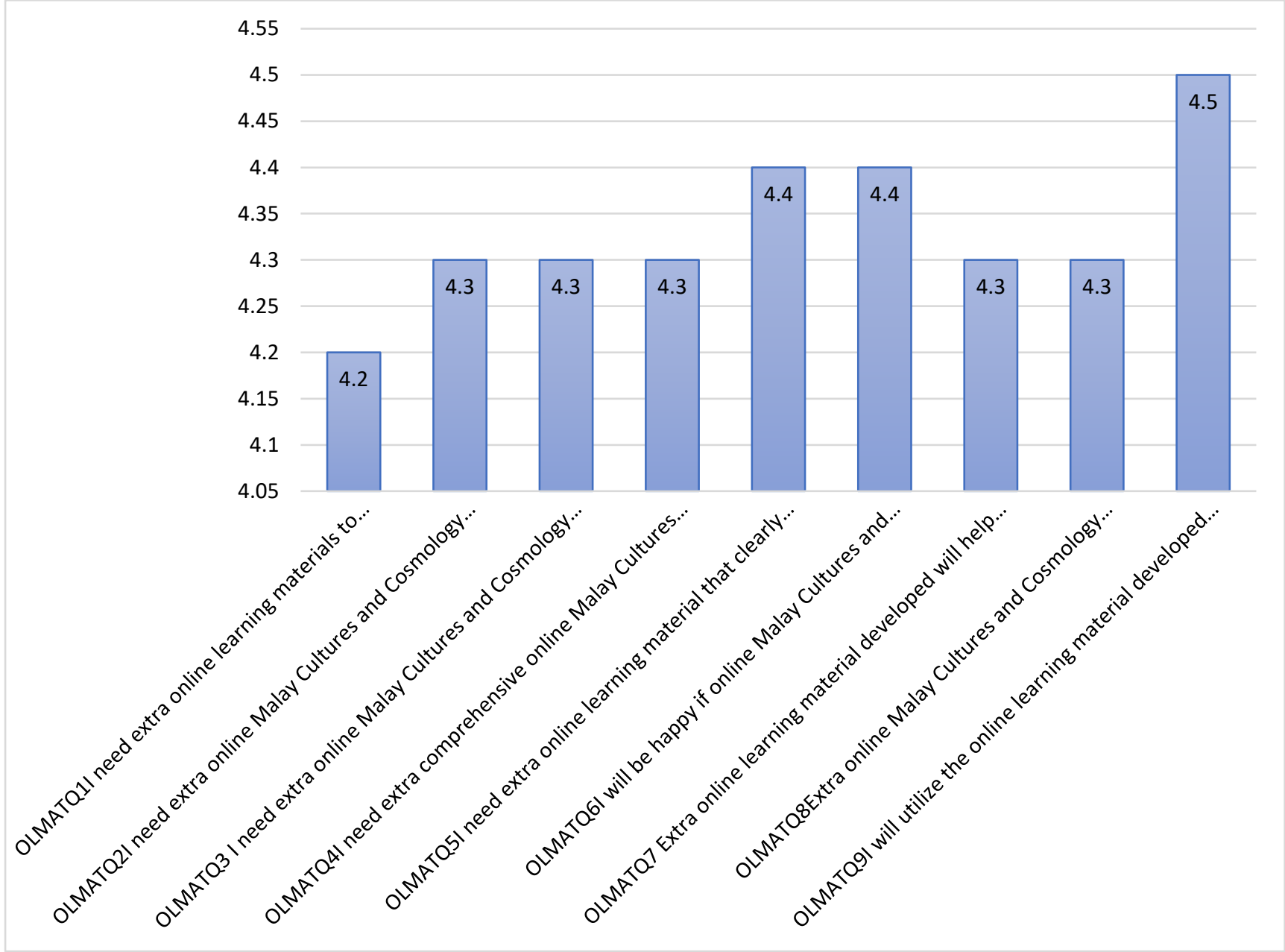

Figure 10 Mean Score for Organization needs

Figure 10 shows the mean distribution for Organization Needs. Most respondents agree that they need extra online learning material to understand the Malay Cultures and Cosmology concepts ( $M=4.2$ ). Most of them also agree that they need an additional online Malay Cultures and Cosmology learning material that can be accessed at any time $(M=4.3)$ and anywhere $(M=4.3)$. They also agree that extra comprehensive online Malay Cultures and Cosmology learning material is needed $(M=4.3)$ as well as extra online learning material that clearly explains the Malay Cultures and Cosmology concepts $(M=4.4)$. Most respondents agree that they will be happy if online Malay Cultures and Cosmology learning material is provided $(M=4.4)$ and will utilise it if it is developed by the lecturers $(M=4.5)$. They can use it as preparation before class $(\mathrm{M}=4.3)$.

\section{Conclusion}

\section{Summary of Findings and Discussion}

In conclusion, it is found that internet access enables respondents as students to communicate with their friends and lecturers if they do not understand the concepts of Malay 
Culture and Cosmology that they have learned. It shows that technology enables them to be connected within the community or network. This finding is supported by Hazaymeh's (2021) study that states online learning empowers students to develop high scores of creativities and innovation, communication and collaboration, research and information fluency, critical thinking, problem-solving, decision-making, and digital citizenship. In addition, one of the premises for connectivism (Downes, 2007) is that knowledge is present in a network of connections. The learning process lies in the ability to construct and traverse these networks (Shriram \& Warner, 2010).

It is also found that the students need extra online learning material to facilitate their learning and to prepare before class. The use of online learning materials has been perceived as a great learning resource as well as a unique way of learning (Erlina, 2018). Therefore, it is high time for the Malay Culture and Cosmology course to develop extra online learning material to enhance students' knowledge and help them in their learning. As stated by Siemens (2006), the theories of learning need to adapt to the changing dynamics of the workforce and the technological resources.

Ease of access to educational materials and the ability to choose the time and place to study were shown as the strongest advantages of online learning materials (Bączek, et. al., 2021). Furthermore, e-learning enables learning materials to be quickly delivered to students, standardised, and if needed, updated (Zehry, Halder \& Theodosiou, 2011).

\section{Pedagogical Implications and Suggestions for Future Research}

This study shows that pedagogy in education has changed. The current education system sees a different spectrum in the way of teaching and learning. Teachers or educators are no longer the main sources of knowledge. Chalk and blackboard-assisted class have been long gone. For some regions, it is considered irrelevant. To be relevant to current education system, teaching and learning methods should be improvised. It is not only in line with the latest scenario but also can enhance students' learning. Furthermore, essential elements such as resources, knowledge, information, and experience in their online learning can be incorporated into the pedagogy too (Jackson \& Klobas, 2008).

Educators have to provide appropriate learning materials so that they can facilitate students' learning. The development of online learning material should consider many aspects. Learning platforms used to facilitate students' learning are among them (Paolini, 2015). Not only sharing notes, but these platforms also can create a conducive learning environment that permits healthy communication. They also should be the catalyst to ensure that the learning outcomes are achieved.

Therefore, it is suggested that a study on the effectiveness of using QR codes be done. It is important to look at the usefulness of the platform used and the contents of the learning material. The study may suggest improvements in preparing the improvised learning materials and the platforms or medium used to share them.

\section{References}

Abdul Rahman, M. Z., \& Abdul Jabar, M. A. (2014). Pengaruh budaya tempatan dalam pembelajaran bahasa Arab di sekolah. Procedia - Social and Behavioral Sciences, 134, 373 - 381. Retrived from https://reader.elsevier.com/reader/sd/pii/S1877042814031693?token=0AC7B5333F5 D0975B9F129839C9D8FC2D1FBBCFC7A0EB7AB63A8FA192D313F6007A0C5B1730A59 $B 6 A 395 D E 6 D 1 C 76 B E 12$ \&originRegion=eu-west-1\&originCreation=20211008085731. 
Anderson, T., \& Elloumi, F. (eds.). (2004). Theory and Practice of Online Learning. Athabasca University.

http://citeseerx.ist.psu.edu/viewdoc/download?doi=10.1.1.131.9849\&rep=rep1\&type $=$ pdf

Bahrum, N. B., \& Samsudin, M. A. (2021). Kesan Pendekatan Pembelajaran STEM Secara Teradun Dalam Bilik Darjah Sains. Innovative Teaching and Learning Journal, 5(1), $12-$ 22. Retrieved from https://itlj.utm.my/index.php/itlj/article/view/59

Baharudin, M., \& Ikhsan, S. A. (2016). The Interesting Teaching and Learning of Malay Language to Foreign Speakers: Language through Cultures. Dinamika IImu. Vol. 16 No. 1, 2016 P-ISSN: 1411-3031; E-ISSN: 2442-9651. http://dx.doi.org/10.21093/di.v16i1.295

Blake, R. (2011). Current trends in online language learning. Annual Review in Applied Linguistics, 31, 19-35. https://doi:10.1017/S026719051100002X).

Doan Thi Hue Dung. (2020). The Advantages and Disadvantages of Virtual Learning. IOSR Journal of Research \& Method in Education (IOSR-JRME), 10(3): pp. 45-48. Retrieved from https://www.iosrjournals.org/iosr-jrme/papers/Vol-10\%20lssue-3/Series5/H1003054548.pdf

Downes, S. (2006). Learning Networks and Connective Knowledge. https:// DOI:10.4018/9781-60566-729-4.CH001.

Downes, S. (2007). An introduction to connective knowledge. Hug, T. (Ed.). Media, Knowledge \& Education: Exploring New Spaces, Relations and Dynamics in Digital Media Ecologies. Proceedings of the International Conference, 77-102. 25-26 June. http://library.oapen.org/handle/20.500.12657/33882 Innsbruck University Press.

Erlina. (2018). Using Authentic Online Materials for Speaking Class: A Study of Students' Perception about the teaching and learning of English as a Foreign Language. Proceedings of the First Indonesian Communication Forum of Teacher Training and Education Faculty Leaders International Conference on Education 2017 (ICE 2017). Atlantis Press. https://doi.org/10.2991/ice-17.2018.86. 18-20 May 2017.

Hassan, Z., Christopher, S. N., \& Musa, N. (2021). Keberkesanan Penggunaan Library QR Book at KKKMS dari Segi Pengetahuan dan Minat Membaca Dalam Kalangan pelajar Kolej Komuniti Kota Marudu, Sabah. International Journal of Humanities Technology and Civilization (IJHTC), 10(1), 80-92.

https://journal.ump.edu.my/ijhtc/article/view/6233/1226

Hazaymeh, W. A. (2021). EFL students' perceptions of online distance learning for enhancing English language learning during Covid-19 pandemic. International Journal of Instruction, 14(3), 501-518. https://doi.org/10.29333/iji.2021.14329a.

Hockly, N. (2015) Developments in online language learning. ELT Journal 69(3): 30813.https://doi.org/10.1093/elt/ccv020. Retrieved from https://www.researchgate.net/publication/276427234_Developments_in_online_lang uage_learning.

Husin, N. (2016). Translation Brief in Translation Procedures of Nonmaterial Cultural Elements. Journal of Applied Environmental and Biological Sciences. 7(1S)65-71, 2017. https://www.textroad.com/pdf/JAEBS/J.\%20Appl.\%20Environ.\%20Biol.\%20Sci.,\%207( 1S)65-71,\%202017.pdf

Huynh, R. (2017). The Role of E-Learning in Medical Education. Academic Medicine: April 2017 - Volume 92 - Issue 4 - p 430. https://doi: 10.1097/ACM.0000000000001596.

Jackson, P., \& Klobas, J. (2008). Transactive memory systems in organizations: Implications for knowledge directories. Decision Support Systems, 44, 409-424. 
https://doi.org/10.1016/j.dss.2007.05.001

Kuama, S., \& Intharaksa, U. (2016) Is Online Learning Suitable for All English Language Students. PASAA: Journal of Language Teaching and Learning in Thailand, 52, (53-82). Retrieved from https://files.eric.ed.gov/fulltext/EJ1134684.pdf

Kulik, J. A., \& Fletcher, J. D. (2016). Effectiveness of intelligent tutoring systems: A Meta Analytics Review. Review of Educational Research, 86(1), 42-78. https://doi.org/10.3102\%2F0034654315581420 Retrieved from https://www.researchgate.net/publication/277636218_Effectiveness_of_Intelligent_T utoring_Systems_A_Meta-Analytic_Review

Martin, F., \& Bolliger, D. U. (2018). Engagement matters: Student perceptions on the importance of engagement strategies in the online learning environment. Online Learning 22(1), 205- 222. http://doi.dx/10.24059/olj.v22i1.1092

Martin, F., \& Ertzberger, J. (2013). Here and now mobile learning: An experimental study on the use of mobile technology. Computers \& Education, 68, 76-85. https://doi.org/10.1016/j.compedu.2013.04.021

McGehee, W., \& Thayer, P. W. (1961). Training in Business and Industry. New York: John Wiley $\&$ Sons.

Mohammadi, N., Ghorbani, V., \& Hamidi, F. (2011). Procedia Computer Science Effects of elearning on Language Learning. Procedia Computer Science, 3, 464-468. DOI:10.1016/j.procs.2010.12.078 Retrieved from https://www.researchgate.net/publication/220308378_Effects_of_elearning_on_Language_Learning

Yakin, M. H. S. (2017). Pengaruh Budaya Tradisi dan Islam dalam Evolusi Adat dan Ritual Kematian Komuniti Bajau. Journal of Southeast Asia Social Science and Humanities Vol. 87 (3). https://ejournals.ukm.my/akademika/article/view/13978

Muthuprasad, T., Aiswarya, S., Aditya, K. S., Girish K. J. (2021). Students' perception and Preference for Online Education in India During COVID -19 Pandemic. Social Sciences \& Humanities Open. 3 (1). https://doi.org/10.1016/j.ssaho.2020.100101.

Paolini, A. (2015). Enhancing Teaching Effectiveness and Student Learning Outcomes. The Journal of Effective Teaching, 15(1), 20-33. Retrieved from https://files.eric.ed.gov/fulltext/EJ1060429.pdf

Saleh, N., Saud, S., \& Asnur, M. N. A. (2018). Pemanfaatan QR-Code sebagai media pembelajaran Bahasa Asing pada Perguruan Tinggi di Indonesia. Seminar Nasionalis Dies Natalis UNM Ke 57, 253-260. http://eprints.unm.ac.id/id/eprint/11298

Salmon, G. (2013). E-tivities: The Key to Active Online Learning. Second Edition. London and New York: Routledge.

Scupin, R., \& DeCorse, C. (2001) Anthropology: A Global Perspective. Prentice-Hall.

Setyaningrum, A. (2002). Kajian Budaya Kontemporer. Jurnal IImu Sosial dan IImu Politik, 6(2), 229-249.

https://www.researchgate.net/publication/279646633_Kajian_Budaya_Kontemporer

Shopova, T. (2014). Digital literacy of students and its improvement at the university", Journal on Efficiency and Responsibility in Education and Science, 7(2) (pp.26-32). https://doi.org/10.7160/eriesj.2014.070201

Shriram, R., \& Warner, S. C. (2010). Connectivism and the Impact of Web 2.0 Technologies on Education. Asian Journal of Distance Education, 8(2), 4-17. https://scholar.google.com/citations?view_op=view_citation\&hl=en\&user=VK8nNOgA AAAJ\&citation_for_view=VK8nNOgAAAAJ:u-x6o8ySG0sC 
Siemens, G. (2004). A learning theory for the digital age. Retrieved from https:// www.elearnspace.org/articles/connectivism.htm.

Sidin, R. (2000). Kualiti Pengajaran dan Pembelajaran Universiti Tempatan. Akademika, 57, 25-40. https://ejournal.ukm.my/akademika/article/view/2979

Siemens, G. (2006). Connectivism vs. Constructivism. http://www.differencebetween.net/miscellaneous/the-difference-betweenconnectivism-and-constructivism/

Solak, E., \& Cakir, R. (2015). Language Learning Strategies of Language e-Learners in Turkey. E-Learning and Digital Media, 12(1), 107-120. https://doi.org/10.1177/2042753014558384

Stockwell, Esther. (2018). Teaching culture in foreign language classes. Foreign Language Education Research, 22, 11-23. Retrieved from https://sspace.snu.ac.kr/bitstream/10371/142718/1/2\%20E.Stockwell_Final_Commented.pdf

García-Carbonell, A., \& Rising, B. (2006). Culture and communication. Georgia: College of Management Georgia Institute of Technology Atlanta, Georgia, 23-40. Retrieved from http://www.upv.es/diaal/publicaciones/rising1.pdf

Mahadi, T. A., \& Jafari, S. M. (2012)._Language and Culture. International Journal of Humanities and Social Science, 2(17), 230-235. Retrieved from http://ijhssnet.com/journals/Vol_2_No_17_September_2012/24.pdf

Thio, A. (2005). Sociology: A Brief Introduction. London: Pearson/Allyn and Bacon.

Ting-Toomey. (1999). Communicating Across Cultures. New York: Guilford Press.

Tsai, M.-J. (2009). The Model of Strategic e-Learning: Understanding and Evaluating Student e-Learning from Metacognitive Perspectives. Educational Technology \& Society, 12 (1),34-48. Retrieved from

https://www.researchgate.net/publication/220374300_The_Model_of_Strategic_eLearning_Understanding_and_Evaluating_Student_eLearning_from_Metacognitive_Perspectives

Urdan, T. A., \& Weggen, C. C. (2000). Corporate e-learning: Exploring a new frontier. WR Hambrecht Co. Retrieved from http://papers.cumincad.org/data/works/att/2c7d.content.pdf

Zehry, K., Halder, N., Theodosiou, L. (2011). E-Learning in medical education in the United Kingdom.Procedia Social and Behavioral Sciences 15 (2011) 3163-3167. https://doi:10.1016/j.sbspro.2011.04.265

Zaini, M. H., \& Siraj, S. (2016). Kebolehlaksanaan Penggunaan Kod Quick Response Terhadap Pembelajaran Herba Kesihatan Dalam Kalangan Pelajar Institut Pengajian Tinggi Malaysia. Jurnal Kurikulum \& Pengajaran Asia Pasifik, 4, 20-30. https://juku.um.edu.my/index.php/JUKU/article/view/8196/5669 